\title{
Reduction of testosterone levels in Schistosoma haematobium-or Schistosoma mansoni-infected men: a cross-sectional study in two schistosomiasis-endemic areas of the Adamawa region of Cameroon
}

Hermine BOUKENG JATSA ( $\sim$ mjatsa@yahoo.fr)

University of Yaounde I: Universite de Yaounde I https://orcid.org/0000-0002-9838-8570

Ulrich MEMBE FEMOE

University of Yaounde I: Universite de Yaounde I

\section{Calvine NOUMEDEM DONGMO}

University of Yaounde I: Universite de Yaounde I

Romuald Issiaka NGASSAM KAMWA

University of Maroua: Universite de Maroua

Betrand NONO FESUH

University of Yaounde I: Universite de Yaounde I

Louis-Albert TCHUEM TCHUENTE

University of Yaounde I: Universite de Yaounde I

Pierre KAMTCHOUING

University of Yaounde I: Universite de Yaounde I

\section{Research Article}

Keywords: male genital schistosomiasis, testosterone, testes, Schistosoma haematobium, Schistosoma mansoni, Cameroon

Posted Date: October 15th, 2021

DOI: https://doi.org/10.21203/rs.3.rs-915844/v2

License: (c) (i) This work is licensed under a Creative Commons Attribution 4.0 International License. Read Full License

Version of Record: A version of this preprint was published at BMC Infectious Diseases on March 7th, 2022. See the published version at https://doi.org/10.1186/s12879-022-07195-8. 


\section{Abstract}

Background: The incidence of schistosomiasis-induced male reproductive dysfunction and infertility is probably underestimated compared to female genital schistosomiasis. This study aimed to investigate the impact of $S$. haematobium or $S$. mansoni infection on the reproductive function of adult men in Tibati and Wouldé, two schistosomiasis endemic areas in the Adamawa region of Cameroon.

Methods: A total of 89 men of reproductive age (range: 14 - 56 years) from two localities were enrolled in the study, with 51 in Tibati and 38 in Wouldé. Each participant was submitted to a questionnaire to document data on sociodemographic and stream contact behaviors. A medical examination was performed to measure the circumference of the testes and to evaluate genital tract pathologies. Stool and urine samples were collected and screened for the presence of $S$. haematobium or S. mansoni ova. Blood serum was used to evaluate the levels of transaminases and testosterone.

Results: S. haematobium was present only in Tibati, with a prevalence of $31.37 \%$. The $S$. mansoni prevalence was $3.92 \%$ at Tibati and $44.71 \%$ in Wouldé. The intensity of infection was $22.12 \pm 9.57 \mathrm{eggs} / 10 \mathrm{~mL}$ for S. haematobium and $128.10 \pm 3.76 \mathrm{epg}$ for $S$. mansoni. Serum transaminase activity and the mean testicular circumference of Schistosoma-positive individuals were close to those of Schistosoma-negative individuals. However, the testes size was higher in $S$. mansoni-positive individuals than in $S$. haematobium-positive individuals $(P<0.05)$. The serum testosterone levels of $S$. haematobium-and $S$. mansoni-positive men were significantly reduced by $56.07 \%(P<$ $0.001)$ and $51.94 \%(P<0.01)$, respectively, in comparison to those of Schistosoma-negative men. A significant and negative correlation was established between schistosomiasis and the low level of serum testosterone. Male genital tract pathologies such as scrotal abnormalities, varicocele, nodular epididymis, inguinal hernia and hydrocele were recorded in both Schistosoma-positive and Schistosoma-negative men. However, no significant link was established between schistosomiasis infection and these pathologies.

Conclusion: These results demonstrated that infection with S. haematobium or S. mansoni is associated with low production of the reproductive hormone testosterone and may be a major cause of male infertility.

\section{Introduction}

Schistosomiasis is an acute and chronic disease caused by blood flukes of the genus Schistosoma. In Cameroon, three species of human schistosomes occur: $S$. haematobium, S. mansoni and S. guineensis. People are infected while exposed to infested water during routine agricultural, domestic, occupational, and recreational activities. In 2016, the global burden of schistosomiasis was estimated at 2.50 million disability-adjusted life years (DALYs). Schistosomiasis remains a major public health problem, with at least 229 million people worldwide, and almost $90 \%$ of them lived in sub-Saharan Africa, requiring preventive chemotherapy in 2018 [1]. In Cameroon, it was estimated that $47 \%$ of the population (9 484894 million) was at risk of schistosomiasis infection and needed preventive treatment in 2010 [2]. The three northern regions of the country, namely, Far North, North and Adamawa, are the most affected, and some health districts in the South-West, Littoral, West and Centre regions showed a high prevalence of infection. Epidemiological data collected in some schools of the Adamawa region in 2006 revealed that $14.2 \%$ of the children were infected with at least one of the schistosome species [3]. The strategy of choice to control schistosomiasis remains preventive chemotherapy with praziquantel. School-aged children are the primary target of these therapeutic interventions since they are the most vulnerable group and the most affected by the infection [4]. In Cameroon, fishermen, farmers and irrigation workers are also high-risk groups for schistosome infection, but they are not enrolled in deworming campaigns with praziquantel [3,5]. Schistosoma- 
infected adults generally suffer from chronic schistosomiasis with severe consequences such as liver fibrosis, portal hypertension, ascites, calcification of the bladder, kidney failure and genital dysfunction [2]. Genital schistosomiasis occurs when Schistosoma circulating eggs invade the reproductive tissues of the host. It has been associated with female and male reproductive health problems such as ectopic pregnancies, abortion, low sperm count, coitus pain, vaginal bleeding, genital organ enlargement and infertility [6-8]. Female genital schistosomiasis (FGS) is well documented, and its prevalence is considerable in $S$. haematobium endemic areas (33 to 75\%) [6,9-12]. In contrast to FGS, male genital schistosomiasis (MGS) is underreported, and its burden is underestimated. S. haematobium and $S$. mansoni are the two species involved in MGS. The main findings reported in patients who have travelled or lived in schistosomiasis endemic areas are swelling of scrotum and other genital organs, dilatation and calcification of the prostate and seminal vesicles, haemospermia, hydrocele, changes in semen/ejaculate, infertility and urethral discharge [7,13]. Case reports have mentioned the presence of $S$. haematobium or $S$. mansoni eggs in male genital organs and semen of some young and adult patients [14-24]. Variation in the levels of sex hormones was also reported in some male patients with S. haematobium and/or S. mansoni [25-29].

In Cameroon, investigations on the association of schistosomiasis and the male reproductive tract have drawn no attention from researchers. To the best of our knowledge, this is the first report on male genital schistosomiasis in Cameroon. The aim of this study was to evaluate the impact of infection with $S$. haematobium or $S$. mansoni on the reproductive tract of adult men in Tibati and Wouldé, two schistosomiasis endemic areas in the Adamawa region of Cameroon.

\section{Methods}

\section{Study area}

Cameroon is divided into 10 regions at the first level, 58 divisions at the second level, and 360 subdistricts at the third level. According to the United Nations, the population of Cameroon was estimated to be 25876380 inhabitants in 2019, with 1200970 inhabitants in the Adamawa region [30]. The Adamawa region is divided into five divisions: Vina, Mbéré, Mayo Banyo, Djerem and Faro et Déo. Tibati, the capital of the "Djerem” division, is situated between $6^{\circ} 47^{\prime} \mathrm{N}$ and $12^{\circ} 63^{\prime} \mathrm{E}$. It is a semi-urban area with a population density of 7 inhabitants $/ \mathrm{km}^{2}$. Situated in the "Pagneré" neighborhood, Lake Pagneré is the largest in the city. Trading, fishing and fish mongering are the main activities in Tibati. Wouldé is a village in the Mayo-Baléo subdistrict in the "Faro et Déo" division. It is situated between $7^{\circ} 43^{\prime} \mathrm{N}$ and $12^{\circ} 47^{\prime} \mathrm{E}$ and surrounded by volcanic hills. At the entrance of this rural area flows the Wouldé River with its thermal source. The population density is 6.6 inhabitants $/ \mathrm{km}^{2}$, and the major occupations in this community are farming, livestock and trading (Figure 1). The vegetation of the Adamawa region falls within the rainforest-savannah mosaic, and the climate is a sudano-guinean type with an annual rainfall of $1500 \mathrm{~mm}$. The transmission of schistosomiasis presumably takes place in lake, river, pond and marshy fields. Fulbe and Kutin ethnic groups are predominant in Tibati and Wouldé, and they are mainly Muslims.

\section{Ethical considerations}

This study was approved by the National Ethics Committee of Cameroon (N072/CNE/DNM/08). Surveys were conducted in the communities with the approval of administrative authorities. The objectives of the study were explained to the populations, and informed consent was signed by each participant. The results were sent to each participant at the end of the study, and all infected persons were treated with praziquantel.

\section{Study design}


People involved in the study were all male volunteers who were residents of Lake Pagneré in Tibati and of the "Chefferie" neighbourhood in Wouldé. Seriously ill individuals showing incapacitation were not included in the study. A questionnaire was administered to each participant for personal information, fertility status and history of sexually transmissible infections. Participants underwent physical examination by a male medical practitioner to assess palpation genital tract pathologies such as varicocele, hydrocele, nodular epididymis, scrotal abnormalities and inguinal hernia. The circumference of the two testes was also measured. Initially planned in the study, sperm collection to search for the presence of schistosome ova and to conduct semen analysis was not carried out because of cultural considerations (masturbation being a taboo in those localities). Urine and stool samples as well as blood were collected from each participant for parasitological and biochemical analyses.

\section{Samples collection}

Urine and stool samples were collected in $60 \mathrm{~mL}$ plastic screw-cap vials, and blood was collected in $5 \mathrm{~mL}$ dry tubes between 10.00 a.m. and 14.00 p.m. The samples were transported to the laboratory of the Divisional Hospital of Tibati or to the Health district of Tignère for processing. In the laboratory, each urine sample was agitated to ensure adequate dispersal of eggs, and $10 \mathrm{~mL}$ of urine was filtered through a Nucleopore ${ }^{\circledR}$ filter. The filters were examined by microscopy for the presence of schistosome eggs. Stool samples were examined by a single thick smear technique using a $41.7 \mathrm{mg}$ Kato-Katz template. The number of eggs for each schistosome species was counted, and the intensity of infection was calculated and expressed as eggs per gram of feces (epg) for $S$. mansoni or eggs per $10 \mathrm{ml}$ of urine (eggs/10 $\mathrm{ml}$ ) for $S$. haematobium. Serum obtained from blood samples after coating was kept at $-20^{\circ} \mathrm{C}$ and transported to the laboratory in a cold ice box for the assay.

\section{Evaluation of the level of transaminases}

Serum activities of alanine aminotransferase (ALT) and aspartate aminotransferase (AST) were evaluated by colorimetric methods using Fortress Commercial kits (Fortress Diagnostics, UK) according to the protocol given by the manufacturer. Absorbances were read against the blank at $505 \mathrm{~nm}$, and the ALT and AST activities were determined from their respective standard curves.

\section{Testosterone assay}

Concentrations of serum testosterone were evaluated by an enzyme immunoassay using the Human Testosterone ELISA kit (Invitrogen). A volume of $50 \mu \mathrm{L}$ of standards and samples were dispensed in microtiter plates. After adding $100 \mu \mathrm{L}$ of testosterone - HRP conjugate (testosterone labeled with horseradish peroxidase), plates were incubated for $60 \mathrm{~min}$ at room temperature. The competitive reaction was stopped by washing with wash buffer. A chromogenic solution of 3-3', 5-5' tetramethylbenzidine $(100 \mu \mathrm{L})$ was added to each well, and after incubation for 30 min at room temperature, $100 \mu \mathrm{L}$ of the stop reagent $(\mathrm{HCl} 2 \mathrm{~N})$ was added. Absorbance was read at $450 \mathrm{~nm}$, and testosterone concentrations were determined from the standard curve.

\section{Data analysis}

The data for this study were entered into Excel and exported to R version 3.5.0 software for statistical analysis. In univariate analysis, measures of central tendency and dispersion were reported for quantitative variables, while the frequencies and percentages were reported for the modalities of qualitative variables. In bivariate analysis, frequencies and percentages were determined for Schistosoma-infected and noninfected subjects, respectively, to evaluate its prevalence across groups of other qualitative variables. Equality of prevalence rates was tested using Pearson's chi-squared test for equality of proportions. Differences in distributions for quantitative variables between 
$\mathrm{SCH}$-positive and SCH-negative subjects were tested using the Kolmogorov-Smirnov test. Univariate logistic regression models were used to identify factors that were affected by Schistosoma infection. For the quantitative results of biochemical parameters, data were analysed using GraphPrism 8.0.1 by one-way analysis of variance (ANOVA), and differences between groups were assessed using the Tukey multiple comparison post-test. In all, level of significance was set at 5\%. The intensity of individual infection for S. mansoni (light: 1 - 99 epg; moderate: 100 399 epg; and heavy $\geq 400 \mathrm{epg}$ ) and for $S$. haematobium (light: < 50 eggs/10 mL and heavy: $\geq 50$ eggs/10 mL) was classified according to the WHO guidelines [31].

\section{Results}

\section{Socio-demographic characteristics of the participants}

A total of 89 men of reproductive age (range: 14 - 56 years) were enrolled in this study, with 51 in Tibati and 38 in Wouldé. The mean age of the population was $32.21 \pm 1.16$ years. Regarding the marital status of the participants, 53 (58.43\%) were married, 32 (35.96\%) were single with girlfriends, 4 (4.49\%) were divorced and 1 (1.12\%) was widowed. The results revealed that $49.44 \%$ of the population was permanently in contact with schistosomiasis transmission sites (STSs). Considering the study population per locality, $76.32 \%$ of the participants in Wouldé and $29.41 \%$ in Tibati were exposed to STS. (Table 1).

Table 1 Sociodemographic characteristics of the population of Tibati and Woulde

\begin{tabular}{|c|c|c|c|c|c|c|}
\hline $\begin{array}{l}\text { Sociodemographic } \\
\text { indicators }\end{array}$ & Category & $\begin{array}{l}\text { Study } \\
\text { areas }\end{array}$ & $\begin{array}{c}\text { SCH- } \\
\text { negative } \\
(\mathrm{n}=54)\end{array}$ & $\begin{array}{c}\text { SCH- } \\
\text { positive } \\
(\mathrm{n}=35)\end{array}$ & Total & $\begin{array}{l}\text { Mean } \pm \text { SEM / } \\
\text { Prevalence }\end{array}$ \\
\hline Age (years) & Mean number & & 33.87 & 29.66 & 89 & $32.21 \pm 1.16$ \\
\hline Weight (kg) & Mean number & & 64.37 & 61.43 & 89 & $63.21 \pm 0.89$ \\
\hline Height $(\mathrm{cm})$ & Mean number & & 169.22 & 166.17 & 80 & $167.89 \pm 0.88$ \\
\hline \multirow[t]{6}{*}{ Profession } & \multirow{3}{*}{$\begin{array}{l}\text { No frequent contact } \\
\text { with water }\end{array}$} & Tibati & 21 & 15 & 36 & $70.59 \%$ \\
\hline & & Wouldé & 2 & 7 & 9 & $23.68 \%$ \\
\hline & & Total & 23 & 22 & 45 & $51.68 \%$ \\
\hline & \multirow{3}{*}{$\begin{array}{l}\text { Frequent contact } \\
\text { with water }\end{array}$} & Tibati & 12 & 3 & 15 & $29.41 \%$ \\
\hline & & Wouldé & 19 & 10 & 29 & $76.32 \%$ \\
\hline & & Total & 31 & 13 & 44 & $49.44 \%$ \\
\hline \multirow[t]{4}{*}{ Marital status } & Single & & 16 & 16 & 32 & $35.96 \%$ \\
\hline & Divorced & & 4 & 0 & 4 & $4.49 \%$ \\
\hline & Married & & 34 & 18 & 52 & $58.43 \%$ \\
\hline & Widowed & & 0 & 1 & 1 & $1.12 \%$ \\
\hline
\end{tabular}

Considering the indicator "profession", the prevalence is the percentage of people by locality whose occupation exposes them or not to frequent contact with water.

SCH-negative: negative to Schistosoma infection

SCH-positive: positive to Schistosoma infection 


\section{Prevalence and intensity of infection}

Table 2 summarizes the prevalence and intensity of $S$. haematobium and $S$. mansoni infection in the male adult individuals involved in this study. S. haematobium was the most prevalent species in Tibati, with $31.37 \%$, while the prevalence of S. mansoni was 3.92\%. In Wouldé, S. haematobium was absent among the population of study, and the prevalence of S. mansoni was $44.74 \%$. The egg count for urinary schistosomiasis ranged from 2 to 2620 eggs/10 mL and from 24 to 1224 epg for intestinal schistosomiasis. The geometric mean infection intensity was $22.12 \pm 9.57$ eggs $/ 10 \mathrm{~mL}$ for $S$. haematobium and $128.10 \pm 3.76 \mathrm{epg}$ for $S$. mansoni. According to the degree of intensity of infection, $47.37 \%$ of $S$. mansoni-infected men presented light-intensity infection, $31.58 \%$ moderateintensity infection and $21.05 \%$ heavy-intensity infection. Light-intensity infection with $S$. haematobium represented $68.75 \%$, while heavy-intensity infection was $31.25 \%$. Hematuria was present in $80 \%$ of the men presenting $S$. haematobium heavy-intensity infection (Figure 2).

Table 2 Prevalence and intensity of Schistosoma infection in the male adult population of Tibati and Wouldé

Fig. 2 Degree of Schistosoma infection intensity in the adult male population of Tibati and Wouldé

\section{Legends of Fig. 2}

Light-infection intensity: 1 - 99 epg; moderate-infection intensity: 100 - 399 epg; and heavy-infection intensity $\geq 400$ epg for $S$. mansoni and for $S$. haematobium, light-infection intensity: < 50 eggs/10 $\mathrm{mL}$ and heavy-infection intensity: $\geq 50$ eggs $/ 10 \mathrm{~mL}$

\section{Serum activity of transaminases}

The serum activity of transaminases was evaluated in the study population. The alanine aminotransferase (ALT) and aspartate aminotransferase (AST) activities of $S$. haematobium and $S$. mansoni-positive men were close to those of SCH-negative men. There was thus no significant difference in the serum activity of transaminases between SCH-positive men and SCH-negative men (Table 3).

Table 3 Transaminase activities of Schistosoma haematobium and Schistosoma mansoni-positive individuals of Tibati and Wouldé

\begin{tabular}{cccc}
\hline Transaminases & SCH-negative & S. haematobium-positive & S. mansoni-positive \\
\hline ALT (UI/L) & $12.84 \pm 1.26$ & $12.19 \pm 1.66$ & $13.80 \pm 1.52$ \\
AST (UI/L) & $42.03 \pm 4.26$ & $43.40 \pm 4.70$ & $40.27 \pm 2.44$ \\
\hline
\end{tabular}


The mean testicular circumference of SCH-negative men was $9.26 \pm 0.38 \mathrm{~cm}$, and that of $S$. haematobium-or $S$. mansoni-positive men was $8.28 \pm 0.49 \mathrm{~cm}$ and $10.71 \pm 0.62 \mathrm{~cm}$, respectively. These results revealed no significant difference between SCH-positive individuals and $\mathrm{SCH}$-negative individuals. However, the testicular circumference of S. mansoni-positive men was higher than that of $S$. haematobium-positive men $(P<0.05)$ (Figure 3a).

The serum concentrations of testosterone were $3.40 \pm 0.48 \mathrm{ng} / \mathrm{mL}$ and $3.72 \pm 0.58 \mathrm{ng} / \mathrm{mL}$ for $S$. haematobium-and S. mansoni-positive men, respectively, versus $7.74 \pm 1.07 \mathrm{ng} / \mathrm{mL}$ for $\mathrm{SCH}$-negative men. In comparison to the $\mathrm{SCH}$ negative group, Schistosoma infection induced a significant reduction in the serum level of testosterone by $56.07 \%$ in the $S$. haematobium-positive group $(P<0.001)$ and by $51.94 \%$ in the $S$. mansoni-positive group $(P<0.01)$ (Figure $3 b)$. A strong correlation was observed between Schistosoma infection and the serum level of testosterone in the study population. The Spearman's rho correlation coefficients were $-0.54(P=0.0101)$ and $-0.56(P=0.0006)$ for the groups of $S$. haematobium- and $S$. mansoni-infected men, respectively (Figure 4).

Fig. 3 Mean testes circumferences (A) and serum testosterone levels (B) in Schistosoma haematobium-and Schistosoma mansoni-positive men in Tibati and Wouldé

\section{Legends of Fig. 3}

Data are expressed as mean \pm SEM. ANOVA followed by Tukey’s multiple comparison post hoc test was used for statistical analysis. ${ }^{a} P<0.05$ : values are significantly different from those of $S$. haematobium-positive men. ${ }^{* *} P<$ $0.01,{ }^{* * *} P<0.001$ : values are significantly different from those of SCH-negative men.

Fig. 4 Correlation curves between Schistosoma haematobium (A) or Schistosoma mansoni (B) intensity of infection and serum testosterone levels

\section{Prevalence of genital tract pathologies}

Table 4 shows the prevalence of genital tract pathologies in SCH-negative and SCH-positive men. Physical examination of the population of study revealed that some men infected with S. haematobium or S. mansoni presented one or two of the following pathologies: varicocele, hydrocele, nodular epididymis, scrotal abnormalities and inguinal hernia. Scrotal abnormalities were predominant, with 25 and $52.63 \%$ of the cases in S. haematobium or S. mansoni infection versus $40.74 \%$ of cases in noninfected men. Varicocele and nodular epididymis were also detected in approximately $20.00 \%$ of $\mathrm{SCH}$-positive men. These pathologies were also present in $\mathrm{SCH}$-negative men. The results of the bivariate logistic regression model show that genital tract pathologies are not related to $\mathrm{SCH}$ infection: no significant difference was observed between SCH-negative and SCH-positive men.

Table 4 Prevalence of genital tract pathologies in Schistosoma haematobium-or Schistosoma mansoni-positive men of Tibati and Wouldé

\section{Discussion}

In schistosomiasis endemic areas, people are infected during their routine activities when they are exposed to contaminated water. In this study, approximately half of the population was exposed to schistosomiasis transmission sites due their agricultural and fishing activities. Three-quarters of the study population in Wouldé was 
made up of farmers working in marshy fields around the Wouldé River. The study population in Wouldé was then a high-risk group for schistosomiasis infection [3]. The prevalence of S. haematobium or S. mansoni infection was within the interval of $10-49 \%$, which reflects a moderate occurrence in the study population in Tibati or Wouldé. Despite this moderate endemicity of schistosomiasis, $80 \%$ of men with $S$. haematobium heavy-intensity infection presented hematuria. It reflects the increase in egg population in the urothelium and is sometimes linked to bladder and ureteral calcification and renal failure [32].

Among other complications of urinary schistosomiasis, male reproductive function impairment and even infertility are quite common. S. haematobium is reported to be more involved than S. mansoni [33]. The symptoms include epididymitis, haemospermia, pain during urination, prostatitis, dilatation and calcification of seminal vesicles and testicular inflammation [7,34,35]. In the current study, the mean testicular circumference of $S$. mansoni-positive men was significantly higher than that of $S$. haematobium-positive men. The increased size of the testes could presumably be the consequence of numerous eggs trapped in that organ or/and the inflammation induced by their presence in the testes. The presence of $S$. haematobium or $S$. mansoni ova in the testes has effectively been reported in men living in $\mathrm{SCH}$-endemic areas or tourists who have visited these areas [14,19,21-23,36]. Schistosoma ova in the testes induces direct damage to the testicular tissue by bilharzial inflammation and granuloma formation [37], which could impair testicular steroidogenesis. The testis is an exocrine and endocrine gland that synthesizes and produces testosterone through the process of steroidogenesis in Leydig cells and sperm through spermatogenesis in the seminiferous tubules [38]. When Schistosoma eggs invade the testes, inflammatory cells migrate around eggs and generate granulomatous lesions. Lenzi et al. [39] described the bilharzial granuloma as a structure composed of macrophages, lymphocytes, eosinophils, neutrophils, giant cells and fibroblasts surrounding schistosome eggs. The modulation of Leydig cell steroidogenesis by macrophages has been demonstrated [40-42]. Under normal physiological and noninflammatory conditions, testicular interstitial macrophages play an important role in Leydig cell proliferation and differentiation and stimulate their steroidogenic function $[40,41]$. When macrophages are activated, they produce inflammatory cytokines such as tumor necrosis factor-alpha (TNF-a) and interleukin-1 (IL-1) that inhibit Leydig cell steroidogenesis and thus testosterone production. They also act as transcriptional repressors of steroidogenic enzyme gene expression $[40,43]$. In fact, the exposure of TM3 Leydig cells to the inflammatory cytokines TNF-a, IL-1 $\beta$ and IL- 6 resulted in a decrease in Leydig cell viability and testosterone concentrations [42]. Moreover, the endocrine function of the testis is perturbed by the reactive oxygen species (ROS) generated by macrophages. They impair Leydig cell mitochondria by inhibiting steroidogenic acute regulatory (StAR) protein expression [40]. The significant decrease in testosterone concentration recorded during the current study in S. haematobium-positive men and in S. mansoni-positive men could be linked to the inhibition of Leydig cell steroidogenesis by secretory products of granuloma inflammatory cells. In addition, a significant correlation between $S$. haematobium or $S$. mansoni infection and reduced testosterone levels was established in our study. Hormonal imbalance in SCH-infected individuals is less reported. Authors have recorded decreased levels of hydroxyprogesterone, testosterone and dihydrotestosterone in boys and men presenting hepatosplenic schistosomiasis [26-29]. This was associated with an increased concentration of estradiol, estrone and estriol [25,29], suggesting an intense aromatization of androgens to estrogens in SCH-infected persons. Such sex steroid imbalance has led to delayed puberty in young boys and to hypogonadism in men [27,29].

Authors have described hydrocele, testicular atrophy and nodular scrotum in patients presenting testicular schistosomiasis [21]. In this study, we denoted genital tract pathologies such as scrotal abnormalities, nodular epididymis, varicocele, hydrocele and inguinal hernia in $\mathrm{SCH}$-positive men. Since the prevalence of these pathologies was statistically comparable between $\mathrm{SCH}$-positive and $\mathrm{SCH}$-negative men, it would have become a challenge to establish a correlation between schistosomiasis or reduced testosterone levels and these pathologies. The 
testosterone level of SCH-negative men in this study was, however, similar to that of a control group of men of reproductive age involved in a study on the effect of agropesticides on the male reproductive function of farmers in a village in the West region of Cameroon [44].

The consequence of testosterone depletion in SCH-positive men in Tibati and Wouldé would be poor semen quality since spermatogenesis relies on the ability of Leydig cells to produce testosterone [38]. Due to traditional and cultural beliefs, it was not possible to conduct semen analysis in this study; the population of our study areas considered masturbation (method of sperm collection) as a taboo. Some authors have, however, reported Schistosoma egg excretion in the semen, low volume of ejaculate, decreased sperm viability, oligoasthenoteratozoospermia, azoospermia and sperm apoptosis [15-18,20,36,45-47]. Leukocytospermia, mainly eosinophilia, and secretion of inflammatory cytokines in the semen were also reported in SCH-infected men $[15,17,20,36,45]$. A clinical scheme presenting a low testosterone level and/or poor semen quality could presumably be conducted for subfertility or infertility.

\section{Conclusion}

The results from this study demonstrated that $S$. haematobium and $S$. mansoni infections are associated with a reduction in the male reproductive hormone testosterone of adult men living in schistosomiasis endemic areas in Cameroon. The recommendations from this study are that the national control programme for schistosomiasis and intestinal helminthiasis in Cameroon should accelerate the extension of schistosomiasis treatment to reach all individuals at risk in communities. In addition, a program of sensitization and surveillance of young people and adults suffering from male genital schistosomiasis should be set up in endemic areas.

\section{Declarations}

\section{Ethics approval and consent to participate}

The protocol of the current study was approved by the National Ethics Committee of Cameroon $\left(\mathrm{N}^{\circ}\right.$ 072/CNE/DNM/08). All participants signed an informed consent.

\section{Consent for publication}

All presentations of data have consent for publication.

\section{Availability of data and materials}

The datasets generated and analyzed during the current study are available from the corresponding author on reasonable request.

\section{Competing interests}

The authors declare that they have no competing interests.

\section{Funding}

Financial support was provided by the "Société d'Andrologie de Langue Française" (SALF) for the realization of biochemical study. 
HBJ, LATT and PK conceived and design this study. HBJ and RIKN conducted field study. HBJ, UMF and CND computerized the raw data from the surveys and performed statistical analysis with BNF.

HBJ performed biochemical assays and wrote the first draft of the manuscript with UMF. All authors read and approved the final manuscript.

\section{Acknowledgements}

Authors are grateful to M. Jean Marie Kagho, the medical practitioner who conducted medical examinations of the participants.

\section{Authors' information}

${ }^{1}$ Laboratory of Animal Physiology, Department of Animal Biology and Physiology, Faculty of Science, University of Yaoundé I, P.O. Box 812, Yaoundé, Cameroon

${ }^{2}$ Centre for Schistosomiasis and Parasitology, P.O. Box 7244, Yaoundé, Cameroon

${ }^{3}$ Laboratory of Parasitology and Ecology, Department of Animal Biology and Physiology, Faculty of Science, University of Yaoundé I, P.O. Box 812, Yaoundé, Cameroon

${ }^{4}$ Department of Biological Science, Faculty of Science, University of Maroua, P.O. Box 46, Maroua, Cameroon

${ }^{5}$ Laboratory of Mathematical engineering and information system, Department of Mathematics, National Advances School of Engineering of Yaoundé, University of Yaoundé I, P.O. Box 8390, Yaoundé, Cameroon

\section{References}

1. World Health Organization. Schistosomiasis [Internet]. 2020. Available from: https://www.who.int/newsroom/fact-sheets/detail/schistosomiasis

2. World Health Organization. Progress report 2001-2011 and strategic plan 2012-2020. 2013.

3. Tchuem Tchuente L-A. National Programme for the Control of Schistosomiasis and Intestinal Helminthiasis 2003 - 2019 Progress report Cameroon. 2020.

4. World Health Organization. Preventive chemotherapy in human helminthiasis. 2006.

5. Tchuenté LT, Rollinson D, Stothard JR, Molyneux D. Moving from control to elimination of schistosomiasis in subSaharan Africa: time to change and adapt strategies. Infect Dis Poverty. 2017;6:1-14.

6. Kjetland EF, Leutscher PDC, Ndhlovu PD. A review of female genital schistosomiasis. Trends Parasitol. 2012;28:58-65.

7. Kayuni S, Lampiao F, Makaula P, Juziwelo L, Lacourse EJ, Reinhard-Rupp J, et al. A systematic review with epidemiological update of male genital schistosomiasis (MGS): A call for integrated case management across the health system in sub-Saharan Africa. Parasite Epidemiol Control. 2018;3:e00077. 
8. Sturt AS, Webb EL, Francis SC, Hayes RJ, Bustinduy AL. Beyond the barrier: Female Genital Schistosomiasis as a potential risk factor for HIV-1 acquisition. Acta Trop. 2020;209:105524.

9. Catteau X, Fakhri A, Albert V, Doukoure B, Noël J-C. Genital Schistosomiasis in European Women. ISRN Obstet Gynecol. 2011;2011:1-4.

10. World Health Organization. Female genital schistosomiasis: A pocket atlas for clinical health-care professionals. 2015.

11. Helling-Giese G, Kjetland EF, Gundersen SG, Poggensee G, Richter J, Krantz I, et al. Schistosomiasis in women: Manifestations in the upper reproductive tract. Acta Trop. 1996;62:225-38.

12. Kjetland EF, Ndhlovu PD, Gomo E, Mduluza T, Midzi N, Gwanzura L, et al. Association between genital schistosomiasis and HIV in rural Zimbabwean women. AIDS. 2006;20:593-600.

13. Stecher CW, Kallestrup P, Kjetland EF, Vennervald B, Petersen E. Considering treatment of male genital schistosomiasis as a tool for future HIV prevention: a systematic review. Int J Public Health. 2015;60:839-48.

14. Lopes RI, Leite KR, Prando D, Lopes RN. Testicular schistosomiasis caused by Schistosoma mansoni: A case report from Brazil. Brazilian J Infect Dis. 2007;11:523-4.

15. Pérignon A, Pelicot M, Consigny PH. Genital schistosomiasis in a traveler coming back from Mali. J Travel Med. 2007;14:197-9.

16. Chohan KR, Kling CA, Byler TK. Schistosoma haematobium ova in human semen: a case report. Fertil Steril Reports. 2020;in press:1-3.

17. van Delft F, Visser L, Polderman A, van Lieshout L. Cough and alterations in semen after a tropical swim. Neth J Med. 2007;65:304-6.

18. Al-Qahtani SM, Droupy SJ. Testicular schistosomiasis. Saudi Med J. 2010;31:325-7.

19. Mutengo M, Mudenda V, Mwansa J, Kaonga K, Sianongo S, Wamulume H, et al. Presence of Schistomiasis in genital biopsies from patients at the University Teaching Hospital in Lusaka, Zambia. Med J Zambia. 2010;36:1148.

20. Tayrab E, Ashmarg AK, Shareef H, Bedawi SB, Aradaib IE. Association of Schistosoma mansoni with infertility in a sudanese patient from schistosomiasis area of endemicity: A case report. Res J Med Sci. 2010;4:125-7.

21. Rambau PF, Chandika A, Chalya PL, Jackson K. Scrotal swelling and testicular atrophy due to schistosomiasis in a 9-year-old boy: A case report. Case Rep Infect Dis. 2011;2011:1-3.

22. Adisa J, Egbujo EM, Yahaya BA, Echejoh G. Primary infertility associated with Schistosoma mansoni: A case report from the Jos Plateau, north central Nigeria. Afr Health Sci. 2012;12:563-5.

23. Ondo CZ, Sarr A, Sow Y, Thiam I, Fall B, Sow D, et al. Bilharziome testiculaire à Schistosomia haematobium: à propos de deux observations. Progrès en Urol. 2014;24:67-9. 
24. Ekenze SO, Modekwe VO, Nzegwu MA, Ekpemo SC, Ezomike UO. Testicular schistosomiasis mimicking malignancy in a child: A case report. J Trop Pediatr. 2015;61:304-9.

25. Rizk A, Kader MA, Hashmat H, El Agouz W, Abdalla M. Sex steroids in bilharzial liver affection. 1. estrogens. Acta Biol Med Ger. 1980;39:991-3.

26. Heshmat H, Rizk A, Abdel Kader M, Abdalla M. Sex steroids in bilharzial liver infections. Radioimmunoassay Relat Proced Med 1982. Vienna: International Atomic Energy Agency; 1982. p. 847.

27. Cavaliere H, Leite Z, Medeiros-Neto G. Serum immunoreactive somatomedin-C levels in growth failure and delayed puberty associated with chronic hepatosplenic schistosomiasis. Clin Endocrinol (Oxf). 1986;24:617-26.

28. el-Ridi AM, Aboul-Magd LA, Edris A, Rashed SM, Hamadto HA, Abdalla KF. Serum testosterone level variation in bilharzial male patients. J Egypt Soc Parasitol. 1987;17:87-92.

29. Saad AH, Abdelbaky A, Osman AM, Abdallah KF, Salem D. Possible role of Schistosoma mansoni infection in male hypogonadism. J Egypt Soc Parasitol. 1999;29:307-23.

30. United Nations, Department of Economic and Social Affairs, Population Division. 2019. World population prospects 2019, Online Edition. Rev. 1.

31. WHO. Prevention and control of schistosomiasis and STH. WHO Technical Report. 2002. p. 912: 1-57.

32. Regis L, Lozano F, Lopez-Pacios A M, Morote J. Urogenital schistosomiasis: A diagnosis to consider in patients with hematuria in Europe. UroToday Int J. 2013;6.

33. Ribeiro AR, Luis C, Fernandes R, Botelho MC. Schistosomiasis and infertility: what do we know? Trends Parasitol. 2019. p. 964-71.

34. Vilana R, Corachán M, Gascón J, Valls E, Bru C. Schistosomiasis of the male genital tract: transrectal sonographic findings. J Urol. 1997;158:1491-3.

35. Shebel HM, Elsayes KM, Abou El Atta HM, Elguindy YM, El-Diasty TA. Genitourinary schistosomiasis: Life cycle and radiologic-pathologic findings. Radiographics. 2012;32:1031-46.

36. Hassan A, El-Mogy S, Zalata K, Mostafa T. Testicular schistosomiasis: A case study. Fertil Steril. 2011;95:2124.e1-2124.e4.

37. Abdel-Naser MB, Altenburg A, Zouboulis CC, Wollina U. Schistosomiasis (bilharziasis) and male infertility. Andrologia. 2019;51:1-6.

38. O'Donnell L, Stanton P, de Kretser DM. Endocrinology of the male reproductive system and spermatogenesis. Feingold K, Anawalt B, A Boyce, editors. Endotext. MDText.com, Inc.; 2017.

39. Lenzi HL, Kimmel E, Schechtman H, Pelajo-Machado M, Romanha WS, Pacheco RG, et al. Histoarchitecture of schistosomal granuloma development and involution: morphogenetic and biomechanical approaches. Mem Inst Oswaldo Cruz. 1998;93 SUPPL.:141-51.

40. Hales DB. Testicular macrophage modulation of Leydig cell steroidogenesis. J Reprod Immunol. 2002. p. 3-18. 
41. Hutson JC. Physiologic interactions between macrophages and Leydig cells. Exp Biol Med. 2006;231:1-7.

42. Leisegang $\mathrm{K}$, Henkel R. The in vitro modulation of steroidogenesis by inflammatory cytokines and insulin in TM3 Leydig cells. Reprod Biol Endocrinol. 2018;16:1-11.

43. Hales DB, Diemer T, Hales KH. Role of cytokines in testicular function. Endocrine. 1999;10:201-17.

44. Manfo FPT, Moundipa PF, Déchaud H, Tchana AN, Nantia EA, Zabot MT, et al. Effect of agropesticides use on male reproductive function: A study on farmers in Djutitsa (Cameroon). Environ Toxicol. 2012;27:423-32.

45. Leutscher PDC, Pedersen M, Raharisolo C, Jensen JS, Hoffmann S, Lisse I, et al. Increased prevalence of leukocytes and elevated cytokine levels in semen from Schistosoma haematobium-infected individuals. J Infect Dis. 2005;191:1639-47.

46. Kini S, Dayoub N, Raja A, Pickering S, Thong J. Schistosomiasis-induced male infertility. BMJ Case Rep. 2009;2009.

47. Leutscher PDC, Høst E, Reimert CM. Semen quality in Schistosoma haematobium infected men in Madagascar. Acta Trop. 2009;109:41-4.

\section{Tables}

Table 2 Prevalence and intensity of Schistosoma infection in the male adult population of Tibati and Wouldé

\begin{tabular}{|c|c|c|c|c|c|c|c|c|}
\hline \multirow[t]{2}{*}{ alities } & \multicolumn{4}{|c|}{ Schistosoma haematobium } & \multicolumn{4}{|c|}{ Schistosoma mansoni } \\
\hline & $\begin{array}{c}\text { Number } \\
\text { of } \\
\text { subjects }\end{array}$ & $\begin{array}{c}\text { Number } \\
\text { of } \\
\text { positive }\end{array}$ & $\begin{array}{c}\text { Prevalence } \\
(\%)\end{array}$ & $\begin{array}{l}\text { Intensity } \\
\text { of } \\
\text { infection } \\
\text { (eggs/10 } \\
\text { mL) }\end{array}$ & $\begin{array}{c}\text { Number } \\
\text { of } \\
\text { subjects }\end{array}$ & $\begin{array}{c}\text { Number } \\
\text { of } \\
\text { positive }\end{array}$ & $\begin{array}{c}\text { Prevalence } \\
(\%)\end{array}$ & $\begin{array}{l}\text { Intensity } \\
\text { of } \\
\text { infection } \\
\text { (eggs/g) }\end{array}$ \\
\hline$\overline{\text { iti }}$ & $\begin{array}{c}51 \\
(57.30 \%)\end{array}$ & 16 & 31.37 & $\begin{array}{l}22.12 \\
(6.64- \\
73.72)\end{array}$ & 51 & $\overline{2}$ & $\overline{3.92}$ & 24 \\
\hline lldé & $\begin{array}{c}38 \\
(42.70 \%)\end{array}$ & 0 & 0 & l & 38 & 17 & 44.74 & $\begin{array}{l}128.10 \\
(67.66- \\
242.60)\end{array}$ \\
\hline
\end{tabular}

The geometric mean with $95 \%$ CI is used to express the intensity of infection.

Table 4 Prevalence of genital tract pathologies in Schistosoma haematobium- or Schistosoma mansoni-positive men of Tibati and Wouldé 


\begin{tabular}{|c|c|c|c|c|c|c|c|c|c|}
\hline \multirow[t]{3}{*}{ गlogy } & \multirow{3}{*}{$\begin{array}{c}\text { SCH- } \\
\text { negative } \\
(\mathrm{n}=54) \\
\text { Proportion }\end{array}$} & \multicolumn{8}{|c|}{ Schistosoma-infected individuals } \\
\hline & & \multicolumn{4}{|c|}{ S. haematobium $(\mathrm{n}=16)$} & \multicolumn{4}{|c|}{ S. mansoni $(\mathrm{n}=19)$} \\
\hline & & Proportion & $\begin{array}{l}\text { Odds } \\
\text { ratio }\end{array}$ & $\begin{array}{c}\mathrm{CI} \\
(95 \%)\end{array}$ & $\begin{array}{c}P- \\
\text { value }\end{array}$ & Proportion & $\begin{array}{l}\text { Odds } \\
\text { ratio }\end{array}$ & $\begin{array}{c}\text { CI } \\
(95 \%)\end{array}$ & $\begin{array}{c}P \text { - } \\
\text { value }\end{array}$ \\
\hline $\begin{array}{l}\text { tal } \\
\text { rmalities }\end{array}$ & $\begin{array}{c}22 \\
(40.74 \%)\end{array}$ & $\begin{array}{c}4 \\
(25.00 \%)\end{array}$ & 0.4848 & $\begin{array}{c}.1565- \\
1.6790\end{array}$ & 0.3782 & $\begin{array}{c}10 \\
(52.63 \%)\end{array}$ & 1.6160 & $\begin{array}{c}0.5820 \\
-\end{array}$ & 0.4267 \\
\hline $\begin{array}{l}\text { llar } \\
\text { dymis } \\
\text { :ocele }\end{array}$ & $\begin{array}{c}13 \\
(24.07 \%) \\
11 \\
(20.37 \%)\end{array}$ & $\begin{array}{c}2 \\
(12.50 \%) \\
3(18.78)\end{array}$ & $\begin{array}{l}0.4734 \\
0.9020\end{array}$ & $\begin{array}{c}0.0968- \\
2.1130 \\
0.2407 \\
-\end{array}$ & $\begin{array}{c}0.4919 \\
> \\
0.9999\end{array}$ & $\begin{array}{c}5 \\
(26.32 \%) \\
4 \\
(21.05 \%)\end{array}$ & $\begin{array}{l}1.3990 \\
1.0424\end{array}$ & $\begin{array}{c}4.6740 \\
0.4457 \\
-4.568 \\
0.3250 \\
-\end{array}$ & $\begin{array}{c}0.7461 \\
> \\
0.9999\end{array}$ \\
\hline $\begin{array}{l}\text { nal } \\
\text { a }\end{array}$ & $\begin{array}{c}7 \\
\text { (12.96\%) }\end{array}$ & 1 (6.25\%) & 0.4387 & $\begin{array}{c}3.3764 \\
0.0365- \\
3.0033\end{array}$ & 0.6694 & $\begin{array}{c}4 \\
\text { (21.05\%) }\end{array}$ & 1.8901 & $\begin{array}{c}3.9692 \\
0.5449 \\
- \\
7.9074\end{array}$ & 0.4508 \\
\hline ocele & 4 (7.41\%) & 1 (6.25\%) & 0.7678 & $\begin{array}{l}0.05893 \\
-5.4633\end{array}$ & 0.9999 & $\begin{array}{c}2 \\
(10.53 \%)\end{array}$ & 1.6538 & $\begin{array}{c}0.2865 \\
- \\
7.8212\end{array}$ & 0.6257 \\
\hline
\end{tabular}

\section{Figures}

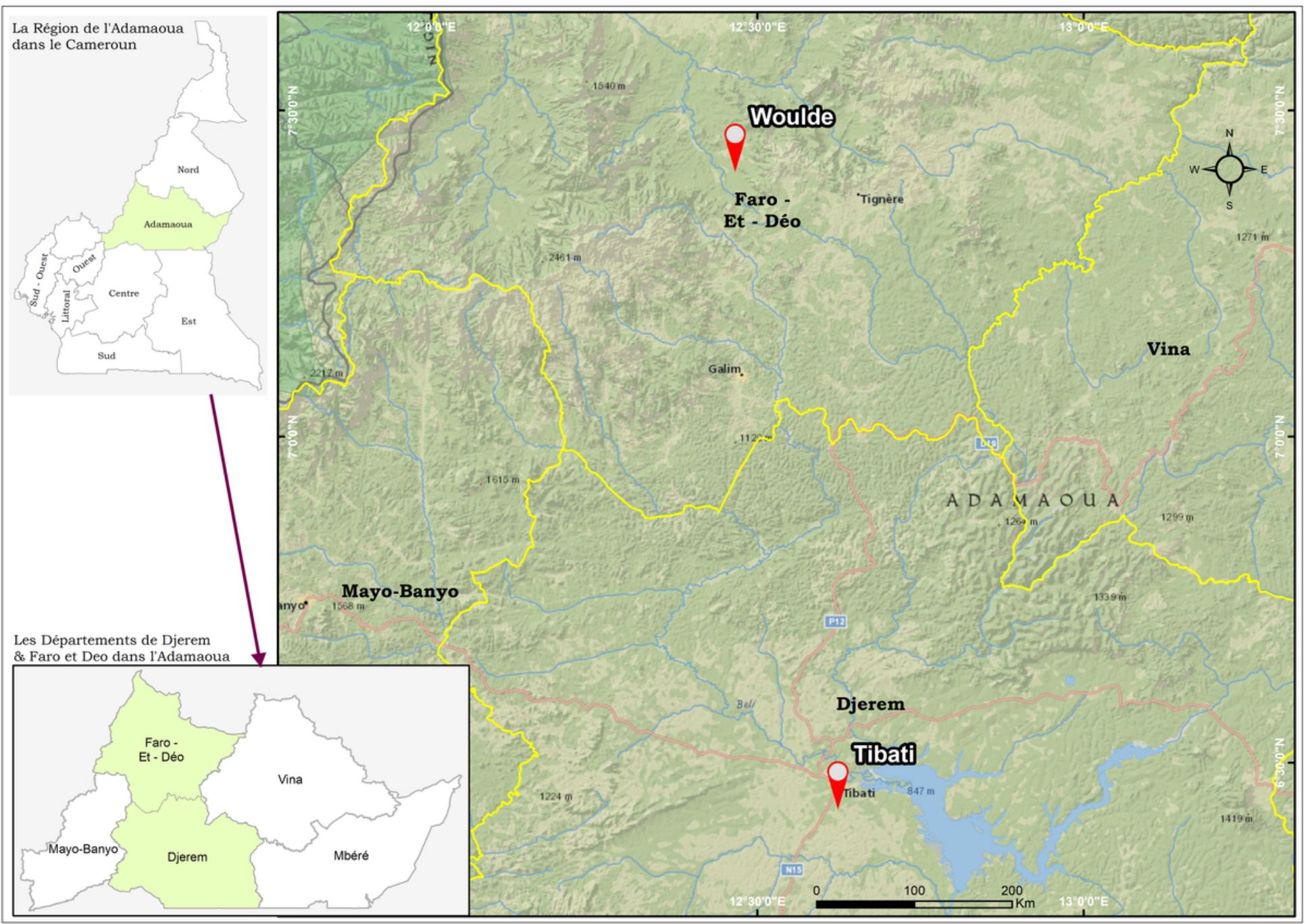

Figure 1 
The vegetation of the Adamawa region falls within the rainforest - savannah mosaic and the climate is a sudano guinean type with an annual rainfall of $1500 \mathrm{~mm}$. Transmission of schistosomiasis presumably takes place at the lake, river, ponds and marshy fields. Fulbe and Kutin ethnic groups are predominant in Tibati and Wouldé and they are mainly Muslims.

\section{S. mansoni intensity of infection}

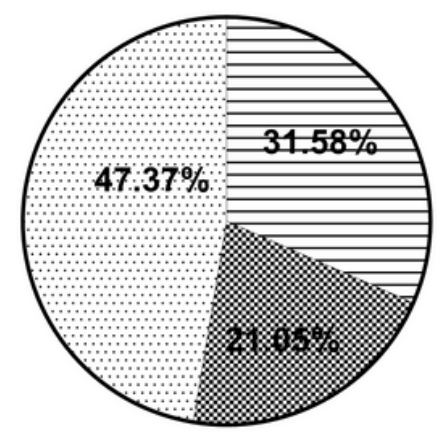

\section{S.haematobium intensity of infection}

\section{Light-intensity infection}

- Moderate-intensity infection

Heavy-intensity infection

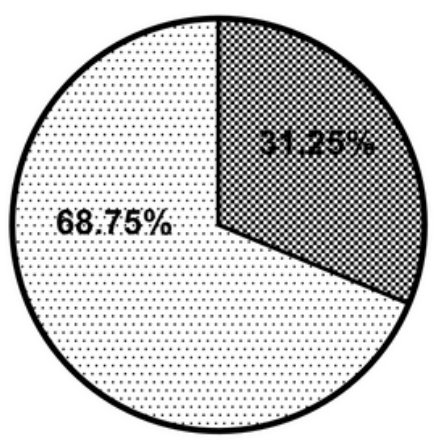

\section{Figure 2}

Degree of Schistosoma infection intensity in the adult male population of Tibati and Wouldé. Light-infection intensity: 1 - 99 epg; moderate-infection intensity: 100 - 399 epg; and heavy-infection intensity $\geq 400$ epg for S. mansoni and for $\mathrm{S}$. haematobium, light-infection intensity: $<50$ eggs $/ 10 \mathrm{~mL}$ and heavy-infection intensity: $\geq 50$ eggs/10 mL 

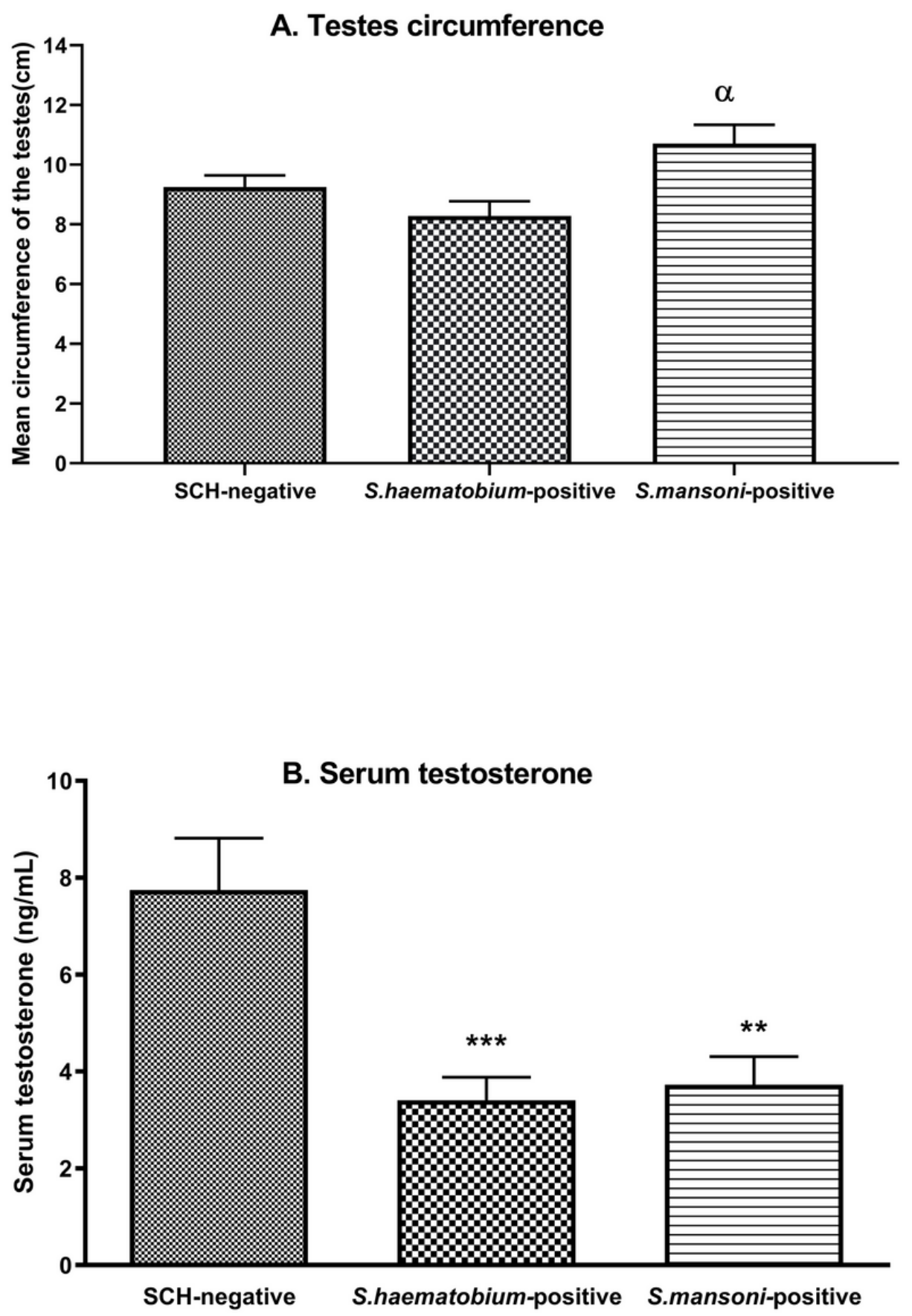

Figure 3

Mean testes circumferences (A) and serum testosterone levels (B) in Schistosoma haematobium- and Schistosoma mansoni-positive men in Tibati and Wouldé. Data are expressed as mean \pm SEM. ANOVA followed by Tukey's multiple comparison post hoc test was used for statistical analysis. $\mathrm{aP}<0.05$ : values are significantly different from those of $S$. haematobium-positive men. ${ }^{*} \mathrm{P}<0.01$, ${ }^{* \star} \mathrm{P}<0.001$ : values are significantly different from those of SCH-negative men. 
A. Correlation between $S$. haematobium infection and serum testosterone level

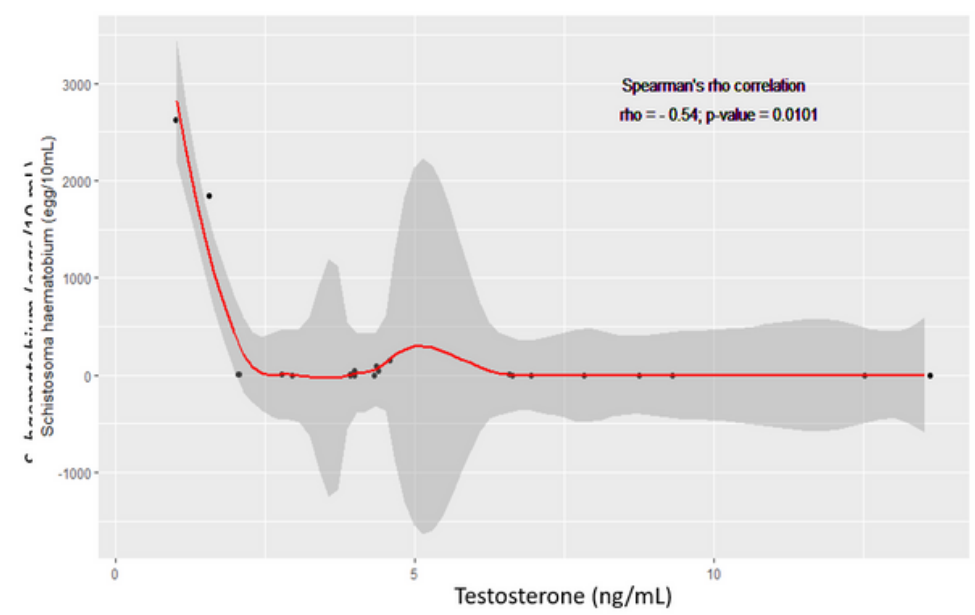

B. Correlation between $S$. mansoni infection and serum testosterone level

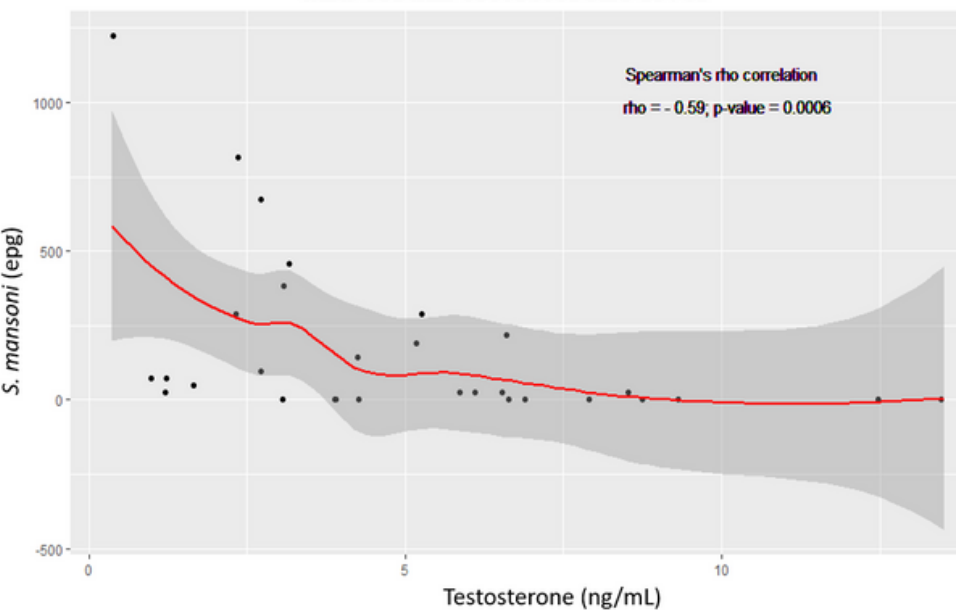

Figure 4

Correlation curves between Schistosoma haematobium (A) or Schistosoma mansoni (B) intensity of infection and serum testosterone levels 